\title{
Agency Structure, Case Selection, and Public Policy: Antitrust Enforcement at the FTC
}

Regulatory Bureaucracy: The Federal Trade Commission and Antitrust Policy. By Robert A. Katzmann. Cambridge: The MIT Press, 1980. Pp. xiii, 223. $\$ 17.50$ (paper $\$ 6.95$ ).

\section{Robert Pitofsky ${ }^{\dagger}$}

The Federal Trade Commission has been through a remarkable transformation. The story is now familiar: the agency was widely regarded for much of its history as inept and ineffectual-preoccupied with relatively trivial economic problems, strangled by procedural delay and influenced, if not controlled, by a series of powerful rural congressmen who dominated its appropriations and oversight committees. ${ }^{1}$ The portrait is unquestionably overdrawn; at the Commission there have been, at all times, many able people and a good number of significant and successful rules, reports, and cases. Nevertheless, in broad outline it is true that the Commission, despite its unusually formidable legislative authority, had failed for the most part to realize its potential.

Then, in the 1960s, the agency began to change. New appointments to the Commission and to the staff generated a spirit of activism and a willingness to study and often challenge what were perceived to be major economic problems and consumer abuses. This new activism was warmly welcomed in Congress, in the tangible form of increased budgets and a newly enacted extension of the agency's legislative authority, and by the public and the press. Toward the end of the 1970s, the mood on the Hill darkened. Responding to increasing skepticism that government regulation can solve most problems at an acceptable cost, many in Congress appeared to conclude that the FTC had come too far too fast. In an intense legislative fight, Congress considered a number of proposals that would have curtailed sharply the Commission's authority. ${ }^{2}$ An even-

$\dagger$ Federal Trade Commissioner.

1. See E. Cox, R. Fellmeth, \& J. Schulz, "The Nader Report" on the Federal Trade Commission 37-95, 129-59 (1969); Report of the ABA Commission to Study the Federal TrAde Conmmission 12-15 (1969) [hereinafter cited as ABA ReporT].

2. See, e.g., [Jan.-June 1980 Transfer Binder] Antrtrust \&: Trade Reg. Rep. (BNA) F-1 (May 1, 1980) (reproducing conference report to H.R. 2313, FTC Reorganization Bill, reflecting compromises after several proposed amendments). 
tual compromise left the Commission's powers and projects almost completely intact, but also left no doubt that Congress was concerned over what the FTC's proper role should be.

In Regulatory Bureaucracy, ${ }^{3}$ Robert Katzmann has written a subtle and intelligent study of the transition from the much criticized Commission of the forties and fifties to the more activist and controversial present agency. His concern is exclusively with antitrust policy. This is somewhat unfortunate since Commission efforts in the consumer protection field, such as its efforts to impose limits on business practices by funeral directors, used car dealers, and hearing aid salesmen, have been politically controversial and recently have attracted close congressional and public attention. Nevertheless, although it may be more accurate and informative to view Commission policy in its multiple guises-consumer protection, antitrust, and economic studiesa book with a narrower focus can provide valuable insights into the development of policy in a regulatory setting.

This study of antitrust policy at the FTC comes at an auspicious time. We may be witnessing the onset of some major changes in economic regulation in this country; one issue for the 1980s is whether and how antitrust's conventional principles will be reconciled to these changes. New thinking about economic regulation responds to a growing recognition that the American economy is not doing very well. Overall economic growth in the 1970s is down almost a third from the $1960 \mathrm{~s}^{4}$ innovation is lagging, ${ }^{5}$ productivity increases are down from those of the late $1960 \mathrm{~s},{ }^{6}$ and there is solid reason for concern about the ability of the United States to compete effectively abroad. ${ }^{7}$

3. R. KatzManN, Regulatory BuReaucracy (1980) [hereinafter cited by page number only].

4. Annual increases in the gross national product in constant 1972 dollars averaged $4.2 \%$ in the 1960 s but only $2.9 \%$ in the 1970 s. ECONOMIC REPORT OF THE PRESIDENT 204-05 (1980) (table B-2).

5. One sign of lagging innovation is that annual dollar investment in industrial research and development has remained roughly constant for over a decade and has declined from $2.1 \%$ of the gross national product in 1964 to $1.6 \%$ in 1978 . See Economic RIPORT OF THE PRESIDENT, supra note 4, at 204 (table B-2) (gross national product figures); National Science foundation, National Patterns of Science and Technology Resources 25, 29 (1980) (investment figures).

6. Output per hour worked increased by about $3.2 \%$ per year in the period 1948 through 1968, but increased by only about $2.2 \%$ in the period 1968 through 1973 and $0.7 \%$ in the period 1974 through 1979 . ECONOMIC REPORT OF THE PRESIDENT, supra note 4 , at 247 (table B-38).

7. For example, imports of foreign autos will account for approximately $27 \%$ of the auto sales in the United States in 1980, based on the first four months, compared to 
With things going so badly it is inevitable that people begin to propose modifications to the accepted ways the economy is regulated.

A first reaction led to deregulation of rate and entry (at the $C A B$, ICC, SEC) and, more importantly, to an increasing tendency within government to adopt regulatory mechanisms more consistent with a free market philosophy. ${ }^{8}$ But rate and entry regulation have probably never affected more than fifteen percent or so of the gross national product. ${ }^{9}$ The broader plea to eliminate misguided regulatory systems, "getting the government off business' back," may solve some problems, but is increasingly perceived as an inadequate solution to others.

More far-reaching changes are likely if business, labor, and government regulators come to agree that problems of industrial growth, innovation, productivity, and foreign trade can only be remedied through new institutional arrangements such as expanded government, business, and labor cooperation. In a new world of "reindustrialization," auto, steel, drug, and chemical manufacturers will seek not only subsidies, import quotas, and tax breaks, but also exemptions from traditional antitrust limitations on cooperation and merger in order to meet the competition of government-sponsored foreign industries. This will trigger a reevaluation, already begun to some extent, of the future role of antitrust. Of course, even now, free market incentives, backed by antitrust enforcement, are rarely relied upon entirely in any market. Assorted elements of competition policy, government regulation, and authorized industry self-regulation always exist, and there is a constant tension between these policies and shifts of emphasis. When things appear to be going badly, there is likely to be a reappraisal. The last time this country lost confidence in the ability of free market incentives to achieve economic goals was in the 1930s, and we then experimented rather unsuccessfully with government-business planning through the NRA.10

If we are in for a world of increased government participation in the industrial process, a major challenge will be not only to see that antitrust and consumer interests are not forgotten in the process of government, business, and labor collaboration, but also to work out

15.2\% in 1970. Subcomm. on Trade of the House Ways and Means Comm., 96th Cong., 2D Sess., Auto Siruation: 1980, at 27 (Comm. Print 1980). The United States' share of world exports of medical and pharmaceutical products has fallen from $27.6 \%$ in 1962 to $16.9 \%$ in 1979. Bus. WEEK, June 30, 1980, at 60 .

8. See Breyer, Analyzing Regulatory Failure: Mismatches, Less Restrictive Alternatives, and Reform, 92 HARv. L. REv. 547, $589-90$ (1979) (airline industry inefficiency one reason for deregulation by $\mathrm{CAB}$ ).

9. See Jones, An Example of a Regulatory Alternative to Antitrust: New York Utilities in the Early Seventies, 73 Colum. L. REv. 462,465 n.1 (1973).

10. See, e.g., A. Schlesinger, The Coming of the New Deal 87-176 (1959). 
how antitrust concerns can be reconciled with new types of cooperation. One of the reasons antitrust policy has been able to adjust to immense economic changes for almost a century is its considerable flexibility, and specifically its capacity to decide what an "unreasonable restraint" is by balancing a wide variety of competitive and other concerns. Antitrust's rule of reason is already sufficiently flexible to incorporate, if need be, considerations of innovation, productivity, and foreign trade as well. For example, the rule of reason could allow modification of conventional antitrust enforcement principles when the transaction relates primarily to joint research or to doing business in foreign markets. Indeed, if prosecutorial discretion is taken into account, these considerations already are a fact of "antitrust law," at least when enforced by the government. But this kind of readjustment, preserving the right mix of antitrust, government regulation, and free market incentives, will not just happen. It requires a complete knowledge of how markets operate, an understanding of competing foreign systems, a realistic conception of the values antitrust and other economic policies are intended to serve, and development of rules and guides indicating how and in what circumstances conventional principles can be altered.

The Antitrust Division of the Department of Justice, because it is part of the executive branch, inevitably will play a key role in any reevaluation process. But the FTC, although it has prosecutorial authority roughly coextensive with that of the Department of Justice, has the capacity to do more. It has a cadre of economists integrated into its planning and enforcement activities, and it has investigative and advisory authority that goes beyond simple prosecution. It could be in a position to contribute to a coordinated approach to these problems, indeed, to become a "trade" agency in the broadest sense, as envisioned by some of its sponsors in 1914. ${ }^{11}$ The role the Commission has played in recent years-sponsoring legislative initiatives, issuing reports to Congress, proposing model state legislation, conducting economic studies, and intervening to assert free market and consumer interests in other regulatory agencies such as the ICC and Department of Energy (all in addition to its usual prosecutorial work) -indicates a capacity to play this crucial role.

II

Although there is an opportunity for the FTC to play a part in any reassessment of antitrust, the agency's record since 1914 of antici-

11. See G. Henderson, The federal Trade Commission 18-19, 24 (1924). 
pating the direction of economic policy is not encouraging. More often, it doggedly challenged practices on theories of absolute liability that, according to legal and economic scholarship and the common consensus, deserved a more discriminating review. Perhaps an indication of the FTC's capacity to respond to a changing regulatory context can be discovered in the major conversion of the Commission's antitrust policy in the late 1960s, which is carefully studied and documented in Regulatory Bureaucracy.

Antitrust policy's most significant and worthwhile effects on the economy have occurred as a result of the successful enforcement of rules that prevent price fixing and market-division cartels among large firms, and rules that prevent horizontal and near-horizontal mergers from producing increasing levels of industrial concentration. Unfortunately, the early FTC was largely active in other parts of the forest. Motivated by a vague populist view that big companies could "leverage" their market power and thereby suppress competitive opportunities of smaller businessmen, ${ }^{12}$ the Commission, year after year, devoted the lion's share of its resources to a literalistic interpretation of the Robinson-Patman Act outlawing various forms of price discrimination. ${ }^{13}$ For similar reasons, it brought many cases challenging tie-in sales and exclusive dealing arrangements on the theory that they contributed significantly to the power of dominant companies to maintain their market position, a view of vertical foreclosure shaken in exhaustive legal and economic scholarship. ${ }^{14}$ Finally, it challenged a variety of unfair and rather insignificant competitive practices under the catch-all provisions of section 5 of the Federal Trade Commission Act, including payola, ${ }^{15}$ trade disparagement, ${ }^{16}$ and misrepre-

12. For an expanded version of this discussion, see Pitofsky, The Political Content of Antitrust, 127 U. PA. L. Rev. 1051 (1979).

13. 15 U.S.C. $\$ \S 13-13 \mathrm{~b}, 21 \mathrm{a}$ (1976). A survey by Professor Posner found that approximately $89 \%$ of the 614 competition cases initiated by the Commission from 1960 through 1964 involved straight Robinson-Patman Act charges, excluding allegations of predatory pricing. From 1965 through 1969, the corresponding figure was 57\%. See Posner, A Statistical Study of Antitrust Enforcement, 13 J.L. \& EcoN. 365, 369, 370 \& n.9 (1970). By contrast, during the period 1975 through 1979 , only six percent of the adjudicative complaints and investigative-stage consent orders issued by the Commission in the competition area alleged Robinson-Patman Act violations. See FTC, Federal Trade Commission AcComplishments, Fiscal Years 1975-1979 (1980). A six percent commitment probably reflects an over-reaction, and that figure will be somewhat higher for this year and next.

14. See, e.g., Bork, Vertical Integration in the Sherman Act: The Legal History of an Economic Misconception, 22 U. CHI. L. REv. 157 (1954); Bowman, Tying Arrangements and the Leverage Problem, 67 YALE L.J. 19 (1957).

15. See 2 TRADE REg. REP. (CCH) If 7903 (1971) (listing payola and commercial bribery orders).

16. See, e.g., FTC v. Keaton Tire \&: Rubber Co., 5 F.T.C. 335, 342-43 (1922) (firm's characterization of automobile parts competitor as "pirate"); Morse, 47 F.T.C. 258, $271-72$ (1950) (company's charge that competing encyclopedia contained outdated facts). 
sentation of product content and origin. ${ }^{17}$ On the plus side, it did achieve a measure of respect after 1950 through successful efforts to develop the law governing conglomerate mergers, ${ }^{18}$ and its economic studies and reports were influential and almost always professionally sound.

A turning point occurred in the 1960s. After the FTC's previous performance had been bitterly criticized by the first of the Nader's Raiders groups, ${ }^{10}$ and that criticism supported in part by a special American Bar Association Commission, ${ }^{20}$ new leadership set out to remedy what they regarded as the errors of the past. Regulatory Bureaucracy is largely a comparative description of pre-1968 and post1968 Commission procedure and practice in the antitrust area.

It is interesting to compare "reform" opportunities in 1968 on the consumer protection and antitrust sides of Commission enforcement. In traditional areas of consumer protection-advertising and credit practices, information disclosures, marketing frauds-many believed that the Commission had been preoccupied by trivial practices, that its remedies had been inadequate, and that it had generally failed to recognize the interplay of free market competitive considerations and outright protection of consumers. ${ }^{21}$ Actually, the Commission had taken on some very tough issues in the fifties and sixties-the cigarette health warning was a leading example-and had laid the groundwork for many of the innovative cases, rules, and remedies later attempted. But there was still a natural agenda of unaddressed issues, developing out of the 1960s consumer movement, which formed a nucleus of "reform" projects. There was also support in Congress and the press for innovative remedies and new legislative authority. The Bureau of Consumer Protection, riding on the then strong tide of consumerism, had little difficulty developing a program that was at once activist,

17. See, e.g., Waltham Watch Co., 64 F.T.C. 1150, 1164-65 (1964) (prohibiting use of "Waltham" to designate watches without statement of country of origin of each component not made entirely in United States); Colognes, Inc., 59 F.T.C. 872, $876-77$ (1961) (prohibiting sale of cologne in bottles of size usually used for perfume without conspicuous statement of contents).

18. See, e.g., FTC v. Procter \&. Gamble Co., 386 U.S. 568 (1967) (appearance of more dominant acquirer in oligopolistic industry is anticompetitive under $\$ 7$ of Clayton Act); FTC v. Consol. Foods Corp., 380 U.S. 592 (1965) (reciprocal buying after acquisition is anticompetitive under $\$ 7$ of Clayton Act); Bendix Corp., [1970-73 Transfer Binder] Trade Reg. ReP. (CCH) \$ 19,288 (1970), rev'd on other grounds, 450 F.2d 534 (6th Cir. 1971) (acquisition by firm in closely related market lessens likelihood acquirer will enter acquiree's market and is anticompetitive).

19. See E. Cox, R. Fellmeth, \& J. Schulz, The Consumer and the Federal Trade CoMmission (1969).

20. See ABA REPORT, supra note 1 .

21. See E. CoX, R. FeLLMETh, \& J. Schulz, supra note 1, at 37-95; ABA Report, supra note 1 , at $36-64$. 
attention getting, and widely, though of course not universally, regarded as worthwhile.

In 1968, there was also a plausible antitrust agenda for an activist program by the Bureau of Competition that did not depend on a purely populist, small-business-oriented view of the competitive process. Section 2 of the Sherman Act, although interpreted in the courts to impose fairly strict limits on permissible behavior by monopolists, had been left largely unenforced since $1950 .{ }^{22}$ Similarly, sophisticated observers of antitrust law had noted the possibility that there might be certain kinds of oligopolistic behavior, extremely anticompetitive in effect and lacking any plausible business justification, that might be considered illegal regardless of the absence of evidence of outright agreement. ${ }^{23}$ Beyond these major but lingering "structural" questions, there was a good deal of single-firm conduct by nonmonopolists that had been regarded with concern, but left virtually unchallenged since World War Two. Part of the problem was that the attempt-to-monopolize clause of the Sherman Act, which could have been applied to plainly anticompetitive conduct by dominant single firms falling short of monopoly power, was also largely unenforced. As with monopolizing conduct, the definition of "predation" necessary to make out an illegal attempt-in pricing, plant expansion, accumulation of patents -remained extremely unclear in the few existing judicial decisions. ${ }^{24}$ Finally, although Congress and the courts had clearly reached a judgment against the legality of vertical price fixing, there was reason to believe that a good deal of indirect resale price maintenance was occurring, and that nonhorizontal mergers with occasional, though elusive, anticompetitive effects were on the increase in the economy.

There was, then, an agenda, but it was in no way comparable to the decades of advertising fraud and marketing abuse by national companies that abruptly began to be challenged by the Bureau of Consumer Protection. Every one of the antitrust issues that the Commission addressed in the 1960s involved competing values and thus

22. Although the main outlines of a section 2 violation had been established in United States v. Aluminum Co. of America, 148 F.2d 416 (2d Cir. 1945), and United States v. United Shoe Mach. Corp., 110 F. Supp. 295 (D. Mass. 1953), aff'd per curiam, 347 U.S. 521 (1954), case enforcement was rare. See Bodner, Monopolization and Attempts to Monopolize: Whatever Happened to Section 2? 41 A.B.A. ANTitrust L.J. 589, 592 (1972) (introductory remarks to panel discussion); Cox, Competition and Section 2 of the Sherman Act, 27 A.B.A. ANTITRUst L.J. 72, 72 (1965).

23. See, e.g., Turner, The Scope of Antitrust and Other Economic Regulatory Policies, 82 HARV. L. REv. 1207, 1225-31 (1969).

24. See Cooper, Attempts and Monopolization: A Mildly Expansionary Answer to the Prophylactic Riddle of Section 2, 72 MICH. L. REv. 373, 435.40 (1974); Turner, The Scope of "Attempt to Monopolize," 30 REC. A.B. CiTY N.Y. 487, 493-94 (1975). 
an over-aggressive enforcement effort would be likely to do more harm than good. To take an obvious example, if the Commission chose to try to expand the definition of "attempt to monopolize" so as to limit permissible pricing or corporate expansion too restrictively, the result would be a net loss to competitive markets of the beneficial effects of aggressive product improvement by large but not yet dominant firms. Moreover, when innovative enforcement projects involved major structural problems, that is, issues of monopoly and shared oligopolistic behavior, they generated cases of incredible length and procedural complexity. Finally, after nearly twenty years during which the Supreme Court had almost automatically ratified any government enforcement initiative, the government in the 1970s found itself losing many of its major antitrust cases. Thus, while the Commission and its senior antitrust staff were under some pressure to replicate the activist program on the consumer protection side, when they did, they found themselves embroiled in long and complex battles.

\section{III}

Despite the difficulties, the Commission, in the years following 1970, did initiate significant antitrust actions against major corporations, including the oil, automobile, breakfast foods, drug, and office-copier industries. ${ }^{25}$ Unquestionably, the present Commission is far more willing than its forebears to take on major economic problems and major corporate interests. This period of heightened antitrust activity, accompanied by a doubling and tripling of its antitrust budget, has been accompanied and caused, to some extent, by major institutional changes within the agency. Regulatory Bureaucracy analyzes these changes, measures the extent of the departures from the institutional arrangements of previous Commissions, attempts to understand the reasons why they have occurred, and discusses the likelihood that they will endure.

The major categories of change that Katzmann examines are shrewdly chosen: departures in the method of case selection and, as a result, changes in the type of cases the agency has been bringing; an increase in the influence of economists in an agency traditionally dom-

25. See, e.g., Eli Lilly \& Co., 3 Trade Reg. Rer. (CCH) 121,612 (1980) (pharmaceutical industry); Investigation of the Automobile Industry, File 7610083 (compulsory process resolution, Aug. 2, 1976) (on file with FTC) (automobile industry); Xerox Corp., 86 F.T.C. 364 (1975) (officc-copier industry); Exxon Corp., [1973-1976 Transfer Binder] TRADE REc. Rer. (CCH) ๆ 20,388 (1973) (oil industry); Kellogg Co., [1970-1973 Transfer Binder] Trade RLG. REP. (CCH) I 19,898 (1972) (breakfast food industry). 
inated by lawyers; an increase in the ability of the agency to attract abler, better qualified staff; and subtle changes in the roles of Commissioners, bureau chiefs, and staff in influencing and controlling agency direction. Katzmann adds a final chapter on why such profound changes occurred and what we are likely to see in the years ahead. Throughout his analysis, he is unusually alert to the possibility that the nuts and bolts of the regulatory world-bureaucratic structure, budgetary and management planning, the interplay of career objectives among attorneys and economists-may influence and even control the substantive output of the agency.

Katzmann understands that the nature of a law enforcement program is determined by case selection values, and he detects, accurately I believe, a significant difference in case selection in the pre-1968 and post-1968 Commission. In the earlier period, the agency pursued, in Katzmann's word, a "reactive" approach that relied on mail bag complaints, frequently forwarded by influential congressmen, as a source of investigations. ${ }^{26}$ The approach produced large numbers of cases of modest scope designed to deter or punish particular kinds of business behavior. In a vintage year, in the fifties and early sixties, the Commission would bring over a hundred Robinson-Patman Act price discrimination and Clayton Act vertical distribution cases, mostly triggered by letter complaints from disadvantaged businessmen; in the same years, it rarely could manage to find and challenge directly questionable instances of monopolistic or oligopolistic behavior by large firms. Part of the reason related to infirmities, real and perceived, in the Commission's remedial authority. Lacking authority to impose criminal sanctions, the FTC sensibly shied away from challenges to outright price fixing and market division cartels, leaving that work for the most part to the Department of Justice. Moreover, for many years prior to 1965, the Commission was influenced by an old Supreme Court decision, ${ }^{27}$ subsequently rejected, ${ }^{28}$ that indicated that the Commission lacked authority to impose structural relief, such as divestiture, even if it successfully challenged an illegal monopoly. But beyond that, the Commission stuck to manageable conduct cases because it believed that was the job Congress wanted it to do. Those cases produced visible and relatively prompt results, and enabled the Commission to avoid resource-intensive life and death struggles with giant corporations or major industries.

26. Pp. 27-31.

27. FTC v. Eastman Kodak Co., 274 U.S. 619 (1927).

28. See Pan Am. World Airways, Inc. v. United States, 371 U.S. 296, 312, 313 \& n.17 (1963). 
Katzmann records that, beginning in the late 1960s, the Commission moved to a "pro-active" approach in which the Bureau of Competition attempted to identify serious structural problems in the economy, usually signaled by high concentration, high profits, and formidable barriers to entry. ${ }^{20} \mathrm{~A}$ decade devoted to seeking out this sort of ambitious and innovative caseload has left the current Commission in strenuous and prolonged litigation battles.

Has the shift toward the pro-active approach made a difference? It is probably too early to tell. As Katzmann notes, this approach in the hands of its more thoughtful advocates never sought a docket of exclusively structural cases, but rather was a reaction against earlier techniques that ignored some of the most serious problems in major sectors of the economy. That much seems to have been achieved. Still, the test of a successful pro-active program is not whether the agency has the will to take on "Big Problems," but whether it has the skill to select sensible targets, draft solid complaints, and litigate successfully against battalions of the ablest defense lawyers in the country. So far, a decade of litigation has produced considerable evidence of dedication (some would say zealotry), ${ }^{30}$ but only modest results; ${ }^{31}$ the jury is still out on the Commission's most ambitious efforts. Unfortunately, the jury may be old and gray before the experiment is over. For example, Katzmann reports that the Commission case against the major United States oil companies, initiated in 1973, has used twelve to fourteen percent of the agency's annual antitrust budget for almost a decade, and that the case is still in an early stage of discovery. ${ }^{32}$

A second facet of bureaucratic change examined by Katzmann relates to recruitment and the interplay between attorneys and economists. At the staff level, the FTC has been in transition. Regarded as a hot agency since 1968, it has attracted the ablest young lawyers and economists. Interestingly, Katzmann records that of 170 attorneys who were on the payroll of the Bureau of Competition in 1975, only 20 were there before 1970,33 a transition pace rarely, if ever, duplicated in other regulatory agencies. There is a downside to the Com-

29. Pp. 31-33.

30. Gellhorn, The Wages of Zealotry: The FTC Under Siege, REgulation, Jan.-Feb. 1980 , at 33 .

31. The Commission settled monopolization proceedings against Xerox and Eli Lilly with orders compelling the licensing, on a royalty-free basis, in part, of significant prescnt and future patents and know-how. Eli Lilly \& Co., 3 TRADE REg. REP. (CCH) 921,612 (1980) (insulin); Xerox Corp., 86 F.T.C. 364 (1975) (office copiers).

32. Pp. 30, 126.

33. P. 77. 
mission's successful recruitment efforts. Because government pay and attorney support services are inferior to those that major law firms offer and because slow-moving structural cases tend to erode morale, the agency's turnover rate is high.

Katzmann also cites as a reason for rapid turnover the absence of "passionate conviction" about the goals of antitrust policy, ${ }^{34}$ but I am not sure he is right. Passionate conviction is difficult to measure, but Commission meetings, and intra-staff differences, have seemed fairly intense to me. In any event, the goals of antitrust at the Department of Justice are said to be about the same as the goals of antitrust at the FTC, and its turnover rate, although high, is not at the FTC's level. Whatever the reasons, the Commission so far, with some notable exceptions, has not developed, as successfully as has the Department of Justice, a cadre of experienced trial attorneys who make a career of public service. Unless the courts are going to bail out government lawyers in antitrust cases, as they did to some extent in the Warren Court years, ${ }^{35}$ legitimate government enforcement efforts will continue, on occasion, to be lost when bright, hard-working, inexperienced lawyers representing the government litigate against bright, hard-working, experienced attorneys from the private bar.

Katzmann reserves some of his most thoughtful comments for that hybrid aspect of Commission structure whereby lawyers and economists merge their talents. The Bureau of Economics itself performs two quite different, and some would say conflicting, regulatory functions. The Division of Economic Evidence advises the Commission on case selection and supports the legal staff in its case enforcement activities. The Divisions of Industry Analyses and of Financial Statistics have wide authority to collect statistics (including supervision of the FTC's controversial line-of-business program which discloses aggregate profitability in different sectors of the economy), and also publish occasional reports and studies on important economic issues. In the Bureau's past, the report and study function was probably paramount; the economic staff, largely excluded from case development, issued influential reports such as those that initiated the creation of the Securities and Exchange Commission and led to the reconsideration and

34. P. 81 .

35. See United States v. Von's Grocery Co., 384 U.S. 270, 301 (1966) (Stewart, J., dissenting) ("The sole consistency that I can find is that in litigation under $\$ 7$, the Government always wins."); United States v. E.I. DuPont de Nemours \& Co., 353 U.S. 586, 609 (1957) (Burton, J., dissenting) (Court used $\S 7$ of Clayton Act to uphold government claim, although case had focused on Sherman Act issues for its eight-year life). 
eventual amendment of section 7 of the Clayton Act, the section covering mergers. ${ }^{36}$

More recently, the Bureau of Economics has achieved much greater influence in policy planning and case selection. This increased role has led to some lively disagreements. Economists tend to be more confident of free market solutions to economic problems and skeptical of conduct cases that attempt to preserve small business units despite their inherent inefficiencies. As a result, economists are rigorous in seeking some indication of real changes likely to result from cases and are cautious in supporting litigation proposals. On the other hand, if there is to be litigation, they support "pro-active" structural cases, believing that challenges to business conduct leave structure unchanged and are a waste of time and effort. According to Katzmann, these disagreements between economists and lawyers occur in part because economists believe their professional prestige and future career advancement depend on a reputation of opposition to unwarranted government interference in the free market. Lawyers tend to be more prosecution minded because their career prospects appear to depend on trial experience. ${ }^{37}$

I doubt that career patterns are that clearly different; many economists now leave the Commission to join consulting firms in which litigation experience is increasingly valuable. But whatever the reasons for the tensions that have occurred, Katzmann draws accurate conclusions. Commission economists have had far more to say about case selection and prosecution, they have frequently opposed traditional Commission initiatives, and their outlook has reinforced the movement toward pro-active, structural cases. Also, the process of rigorous review and occasional challenge by economists has forced Bureau of Competition lawyers to think through their proposals more thoroughly. There is a tendency in a bureaucracy for the working staff to compromise disagreements before they make proposals to the controlling commissioner, administrator, or secretary, downplaying lines of argument that were important in their early thinking. The FTC economists have played something of a devil's advocate role and, in the process, have sharpened important issues for Commission review.

Finally, Katzmann notes that a sensible policy of seeking more com-

36. FTC, The Mferger Movement, A Sumiary Report (1948); FTC, Report on the Prisent Trend of Corporate Mergers and Acquisitions, S. Doc. No. 17, 80th Cong., 1st Sess. (1947); FTC, Report on Blue-Sky Securities (1929) (unpublished report submitted to Congress in Federal Trade Commission Library); see Markham, The Federal Trade Commission's $U_{\text {se }}$ of Economics, 64 ColuM. L. REV. 405, 412-13 (1964).

37. P. 51. 
plex and innovative antitrust cases could only be implemented if there were accompanying reforms in the agency's organization..$^{38}$ Indications of the possibility of these kinds of cases emerge from a review of the consumer price index, indicating high profit sectors of the economy, and from studies of industrial concentration. It would be too much to expect young lawyers fresh from law school to develop such projects; in pro-active cases, the planning is from the top down. That kind of planning, along with the complex cases that result, has become feasible as a result of a number of bureaucratic reforms: first, the accumulation of all antitrust efforts into a single Bureau headed by a single Bureau Director; second, the development of separate Agency and Bureau planning offices with responsibilities to examine the economy for instances of inadequate performance and to explore the possibility that antitrust enforcement could improve the situation; third, the inclusion of economists at early planning stages of case development. Perhaps most significantly, there have been constant indications of a receptivity and willingness at the Commission level to take on the toughest antitrust problems that can be found.

\section{IV}

Where does the FTC go from here? Katzmann reviews and rejects some standard reform proposals-simplification of procedures, contracting for the services of private attorneys, and increased reliance on rulemaking instead of case-by-case enforcement-because they are unlikely to make any real difference. ${ }^{39} \mathrm{He}$ considers the possibility of eliminating the antitrust function of the FTC in favor of exclusive enforcement by the Department of Justice, but rejects the proposal for reasons I think are correct. ${ }^{40}$ The FTC was established in 1914 because Congress believed that antitrust enforcement should not be entrusted exclusively to the executive branch or explored exclusively before federal judges. The FTC was designed to be somewhat closer to Congress and available to conduct its investigations and studies even though they might run counter to administration policy. Also, there are some special advantages to enforcement of the antitrust laws by an administrative agency, in particular, its capacity to integrate economic expertise and to address some problems not only

38. Pp. 187-206.

39. Pp. 188-91.

40. Pp. 191-99. 
through conventional cases but through information gathering, rulemaking, guides, and economic reports. The prosecution-oriented Antitrust Division of the Department of Justice is equally capable of following some of these options, but over the years it has not done so to the same extent as the FTC.

The combination of prosecutorial and judicial functions in a single agency and the potentially broad sweep of its authority to challenge "unfair methods of competition," though, is still troublesome. Because its jurisdiction overlaps almost completely with that of the Department of Justice, proposals to eliminate the FTC's antitrust authority will be floated constantly, particularly when it takes on controversial projects. The Commission's antitrust functions will be subjected to comprehensive review in the coming year, ${ }^{41}$ and significant changes in its mandate and procedures may emerge. A comprehensive review of the Commission's antitrust role is certainly in order, and the results are far from certain. But unless and until the country elects to replace the antitrust policy altogether, it seems a good bet that an FTC, despite its acknowledged flaws and occasional failures, will remain on the scene.

Whether the Commission's style of enforcement should remain the same is a different matter. Katzmann believes "Big Case" pro-active efforts are likely to continue. ${ }^{42}$ But that does not mean they cannot be focused more sharply by careful precomplaint analysis. In many situations anticompetitive industry problems can be challenged without simultaneously reviewing every aspect of competition in the market or suing every company. A trend toward manageable cases and more narrowly focused complaints is probably the most pronounced change in antitrust enforcement in the year or two since Katzmann completed his study.

As noted earlier, another possible change could occur at the borders where competition policy cuts across other economic goals. The world grows smaller in competitive terms and complicated national economic policies intersect increasingly; as a result, it may be that some conventional antitrust problems can be better addressed in a nonlitigation context. In summing up, Katzmann indicates a similar view when he suggests that the Commission's "Big Case" efforts might be supplemented through an increased commitment of resources to information gathering and the publication of studies and reports. ${ }^{43}$

41. See [July-Dec. 1980 Transfer Binder] ANtitrust \& Trade Reg. Rep. (BNA) A-17 (Aug. 7,1980 ) (Senate Consumer Subcommittee promises far-reaching hearings on FTC in 1981).

42. Pp. 202-03.

43. Pp. 203-06. 
One common problem with both economic and legal analyses of competitive issues is that they may have become too parochial, too isolated, too segregated in a separate jargon and point of view. It just may not be possible to look at competitive problems in automobiles, steel, and shoe manufacturing, to cite some obvious examples, as if the values underlying the Sherman, Clayton, and Federal Trade Commission Acts exhausted all relevant considerations. If that is right and if future antitrust policy, to be effective, must integrate previously excluded values, the FTC, with the special advantages of an administrative agency, could have a large role to play in the development of antitrust policy. 